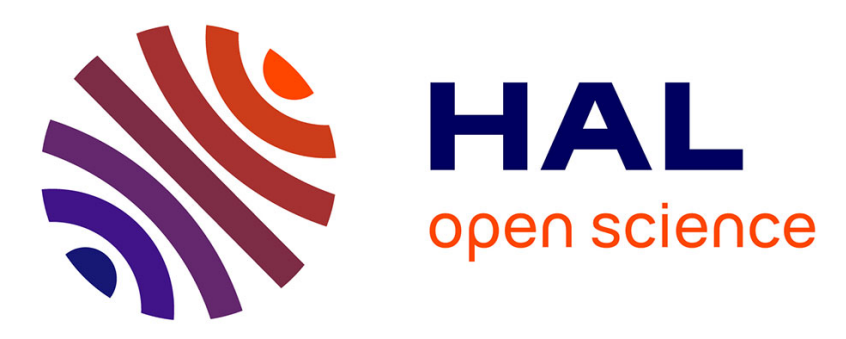

\title{
Elastic Block Model in the North Andean Sliver
}

Paul Jarrin, Jean-Mathieu Nocquet, Frédérique Rolandone, Hector

Mora-Paez, Patricia Mothes

\section{To cite this version:}

Paul Jarrin, Jean-Mathieu Nocquet, Frédérique Rolandone, Hector Mora-Paez, Patricia Mothes. Elastic Block Model in the North Andean Sliver. EGU General Assembly 2021, Apr 2021, online, France. 10.5194/egusphere-egu21-7995 . hal-03185005

\section{HAL Id: hal-03185005 \\ https://hal.sorbonne-universite.fr/hal-03185005}

Submitted on 30 Mar 2021

HAL is a multi-disciplinary open access archive for the deposit and dissemination of scientific research documents, whether they are published or not. The documents may come from teaching and research institutions in France or abroad, or from public or private research centers.
L'archive ouverte pluridisciplinaire HAL, est destinée au dépôt et à la diffusion de documents scientifiques de niveau recherche, publiés ou non, émanant des établissements d'enseignement et de recherche français ou étrangers, des laboratoires publics ou privés. 
EGU21-7995, updated on 30 Mar 2021

https://doi.org/10.5194/egusphere-egu21-7995

EGU General Assembly 2021

(c) Author(s) 2021. This work is distributed under

the Creative Commons Attribution 4.0 License.

\title{
Elastic Block Model in the North Andean Sliver
}

\author{
Paul Jarrin ${ }^{1}$, Jean-Mathieu Nocquet ${ }^{2,3}$, Frederique Rolandone ${ }^{1}$, Hector Mora-Paez ${ }^{4}$, and Patricia \\ Mothes $^{5}$ \\ ${ }^{1}$ Sorbonne University, Institute des Sciences de la Terre de Paris, Paris, France (paulalbertoj@gmail.com) \\ ${ }^{2}$ Géoazur, IRD, Université de Nice Sophia-Antipolis, Observatoire de la Côte d'Azur, CNRS, Valbonne, France \\ ${ }^{3}$ Institut de Physique du Globe de Paris, Université de Paris, Paris, France \\ ${ }^{4}$ Servicio Geológico Colombiano, diagonal 53 Bogotá D.C., Colombia \\ ${ }^{5}$ Instituto Geofísico - Escuela Politécnica Nacional, Quito, Ecuador
}

The North Andean Sliver (hereinafter NAS) lies at the northwestern end of the South American plate (hereinafter SOAM). This extensive area exhibits a complex deformation process controlled by the interactions of Nazca, Caribbean, South America plates, and Panama block, producing crustal seismicity, arc-continental collision, and subduction processes. Previous models based on partial GPS data sets have estimated the NAS kinematics as a single rigid block moving towards northeast at 8-10 mm/yr (Nocquet et al. 2014, Mora-Paez et al 2019). By contrary, geologic interpretations as well as seismotectonic data propose more complex kinematic models based on the interaction of several blocks (Audemard et al 2014, Alvarado et al 2016). Here, we present an updated and most extensive interseismic horizontal velocity field derived from continuous and episodic GPS data between 1994 and 2019 that encompasses the whole North Andean Sliver. We then interpret it, developing a kinematic elastic block model in order to simultaneously estimate rigid block rotations, consistent slip rates at faults and the spatial distribution of interseismic coupling at the Nazca/NAS megathrust interface. Our model is not constrained either by a priori information derived from geologic slip rates or by a priori information of creeping faults. In contrast with previous simplest models, our model will allow us to estimate the degree of slip partitioning more precisely along the NAZCA/SOAM convergence as well as an improved model of interseismic coupling. We will discuss our coupling distribution with respect to previous models, and our block geometry quantifying the goodness of fit, resolution, and considering its consistency with geological interpretations. 